\title{
Cavity resources for Siberian flying squirrel, Pteromys volans orii, in two different habitats in Hokkaido, Japan
}

\author{
Mayuka Marugame, Isao Izumi, Masaki Matsui, Takumi Okahira, \\ Tatsuo Oshida \& Yoshihiro Hayashi
}

\begin{abstract}
The Siberian flying squirrel (Pteromys volans) is arboreal and usually nests in cavities in trunks. The population on Hokkaido Island, Japan, is considered an endemic subspecies (P. volans orii). In mountainous areas of Hokkaido, $P$. volans orii mainly inhabits mixed forests dominated by Picea jezoensis or Abies sachalinensis. To understand these usefulness as $P$. volans orii habitat, we made a preliminary comparison of cavity resources in two different forests common in Hokkaido. Inner space of cavities in $A$. sachalinensis-dominated habitat was significantly larger than that in $P$. jezoensis-dominated habitat. This may mean that A. sachalinensis-dominated habitat provides more useful cavity nests for P. volans orii. Abies sachalinensis is only distributed in Hokkaido and Sakhalin Island and the Kuril Islands of Russia. Pteromys volans orii might have adapted itself into the unique $A$. sachalinensis-dominated forests located on the periphery of $P$. volans distribution.
\end{abstract}

KEY WORDS: Pteromys volans, Picea jezoensis, Abies sachalinensis, mixed forest.

Mayuka Marugame, Isao Izumi, and Tatsuo Oshida* [oshidata@obihiro.ac.jp], Laboratory of Wildlife Ecology, Obihiro University of Agriculture and Veterinary Medicine, Obihiro 080-8555, Japan; Masaki Matsui and Takumi Okahira, University Forest in Hokkaido, The University of Tokyo, Yamabe, Furano 079-1561, Japan; Yoshihiro Hayashi, Faculty of Agriculture, The University of Tokyo, Yayoi, Bunkyo-ku 113-8657, Japan.

*Correspondence author: Tatsuo Oshida

\section{Ресурсы дупел для сибирской летяги, Pteromys volans orii, в двух различных местообитаниях на Хоккайдо, Япония}

\author{
М. Маругами, И. Изуми, М. Матсуи, Т. Окахира, Т. Ошида, Й. Хаяши
}

РЕЗЮМЕ. Сибирская летяга (Pteromys volans) обычно устраивает гнезда в дуплах деревьев. Популяция острова Хоккайдо, Япония, рассматривается в качестве эндемичного подвида (P. volans orii). В горных районах Хоккайдо $P$. volans orii населяет преимущественно смешанные леса с доминированием Picea jezoensis или Abies sachalinensis. Для оценки пригодности этих местообитаний для $P$. volans orii было проведено предварительное сравнение ресурсов дупел в двух различных типах лесов, встречающихся на Хоккайдо. Внутреннее пространство дупел в лесах с доминированием $A$. sachalinensis оказалось значительно крупнее, чем в лесах с доминированием P. jezoensis. Повидимому, местообитания с доминированием A. sachalinensis более привлекательны для создания гнездовых камер P. volans orii. Пихта Abies sachalinensis распространена только на Хоккайдо в Японии и на острове Сахалин и Курильских островах в России. Периферический подвид летяги Pteromys volans orii может быть приспособлен к уникальным лесам с доминированием A. sachalinensis.

КЛЮЧЕВЫЕ СЛОВА: Pteromys volans, Picea jezoensis, Abies sachalinensis, смешанные леса.

\section{Introduction}

Of all flying squirrel species, Pteromys volans (Siberian flying squirrel) has a widest distribution range and occurs in Palearctic taiga (Wilson \& Reeder, 2005). Ognev (1966) described this species as inhabiting spruce (Picea abies)-dominated boreal forests from Finland to eastern Siberia. In Finland, this species prefers sprucedominated mixed forests with deciduous trees for food and large aspens (Populus tremula) for nest cavity trees (Hanski, 1998; Reunanen et al., 2002). In Leningrad, Vologda, and Novgorod provinces, Russia, this species also inhabits mixed forests dominated by conifers and hardwoods such as aspens, birchs, alders, and willows (Novikov et al., 1970).

The Hokkaido population of Siberian flying squirrel is regarded as an endemic subspecies $P$. volans orii (Kuroda, 1921). Phylogeographically, it separated early from the Eurasian populations (Oshida et al., 2005). In the mountainous areas of Hokkaido, P. volans mainly inhabits mixed forests dominated by Picea jezoensis or Abies sachalinensis (Nakano et al., 1991). Both Picea jezoensis and Abies sachalinensis are dominant conifers in the mountainous natural forests of Hok- 


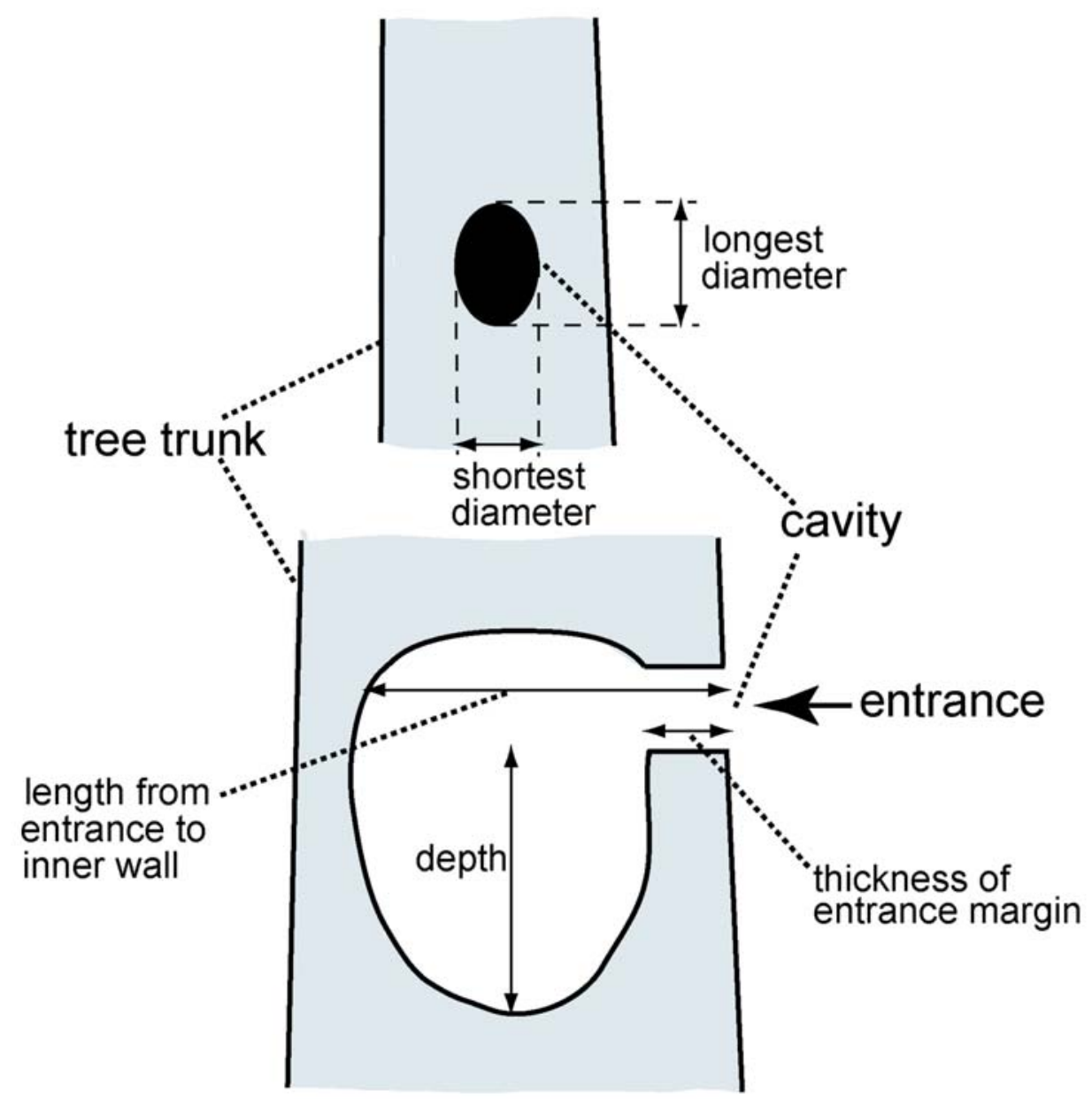

Fig. 1. Measurements used to describe tree cavities according to Masuda (2003).

kaido. Picea jezoensis is distributed in northeastern Russia (Kuril Islands, Sakhalin, Primorskii, and Kamchatka Peninsula), Korean Peninsula, northeastern China, and Hokkaido. Abies sachalinensis is found only in Hokkaido, the southern part of Sakhalin, and Kuril Island (Satake, 1989). Therefore, the forest habitats of $P$. volans orii in Hokkaido are quite different from typical forest habitats in the Eurasian Continent. Since $P$. volans inhabits spruce-dominated mixed forests in Eurasia (Ognev, 1966), we may be able to expect that this flying squirrel prefers the $P$. jezoensis-dominated forest habitat in Hokkaido instead of the $A$. sachalinensis-dominated forest.

In Eurasia, $P$. volans usually uses tree cavities as nests (Airapetyants \& Fokin, 2003), although they are sometimes known to build dreys (Hanski, 1998; Hanski et al., 2000). Also, in Hokkaido, $P$. volans orii usually uses cavities as nests (Nakano et al., 1991; Yanagawa, 1999; Masuda, 2003). To understand habitat preference of $P$. volans orii in Hokkaido, the abundance of cavities could be reasonable and analyzable indicator.

In the present study, as a first step forwards identifying habitat preference of $P$. volans orii, we simply compared cavity resources between two different natural forest habitats in Hokkaido: P. jezoensis-dominated and A. sachalinensis-dominated mixed forests. We discuss which habitat has more abundant nest resource for $P$. volans orii.

\section{Study Area}

This study was conducted in the University Forest in Hokkaido, The University of Tokyo, Furano, Hokkaido, Japan $\left(43^{\circ} 10^{\prime}-20^{\prime} \mathrm{N}, 142^{\circ} 20^{\prime}-40^{\prime} \mathrm{E}\right)$. This natural forest has an area of 22,894 ha and is covered with natural sub-arctic mixed forests. Its dominant stands are Abies sachalinensis, Tilia japonica, Acer mono, and Picea jezoensis (Yamamoto et al., 1995).

\section{Methods}

We surveyed nest cavities from May to October 2008 in 5 A. sachalinensis-dominated 1-ha plots and 5 $P$. jezoensis-dominated 1-ha plots. We concentrated on locating cavities $<4 \mathrm{~m}$ above the ground because it was 
difficult and dangerous to check for cavities located higher up the tree. Cavity trees were described by species, height, diameter at breast height (DBH), diameter at cavity height (DCH), and type (living or snag). We characterized each cavity in each tree with 6 measurements following Masuda (2003): height above ground, longest diameter, shortest diameter, thickness of entrance margin, length from entrance to inner wall, and depth (Fig. 1). We also checked whether they were used by $P$. volans orii. We used a Mann-Whitney $U$-test to compare cavity trees and cavities between the two forest types.

\section{Results}

We found a total of 45 cavities on 44 trees in the $A$. sachalinensis-dominated 1-ha plots and 57 cavities on 47 trees in $P$. jezoensis-dominated 1-ha plots. In the $A$. sachalinensis-dominated habitat, most cavities were in trunks of $A$. sachalinensis. In the $P$. jezoensis-dominated habitat, cavities were mainly on $P$. jezoensis and $A$. sachalinensis (Table 1 ). In the $A$. sachalinensis-dominated habitat, cavities were on 32 live trees and 13 snags. In the $P$. jezoensis-dominated habitat, cavities were on 39 live trees and 8 snags. Between habitats,

Table 1. Cavity tree species in two different habitats of Pteromys volans orii.

\begin{tabular}{|l|c|c|}
\hline \multirow{2}{*}{ Species } & \multicolumn{2}{|c|}{ Number (\%) of cavity trees in habitats } \\
\cline { 2 - 3 } Abies sachalinensis & A. sachalinensis-dominated & P. jezoensis-dominated \\
Picea jezoensis & $22(50.00)$ & $12(25.53)$ \\
Taxus cuspidata & $1(2.27)$ & $15(31.92)$ \\
Magnolia obovata & $1(2.27)$ & 0 \\
Padus ssiori & $1(2.27)$ & 0 \\
Sorbus commixta & 0 & $1(2.13)$ \\
Phellodendron amurense & $2(4.55)$ & $3(6.38)$ \\
Acer mono & $2(4.55)$ & 0 \\
Acer spp. & $3(6.82)$ & $2(4.26)$ \\
Tilia japonica & $7(15.91)$ & $5(10.64)$ \\
Tilia maximowicziana & $2(4.55)$ & $2(4.26)$ \\
Fraxinus mandshurica & $2(4.55)$ & 0 \\
Acer ukurunduense & 0 & $1(2.13)$ \\
Betula ermanii & 0 & $4(8.51)$ \\
unknown & 0 & $2(4.26)$ \\
& $1(2.27)$ & 0 \\
\hline Total & & 47 \\
\hline
\end{tabular}

Table 2. Comparison of mean measurements (SD in parentheses) of cavity trees and cavities between two different Pteromys volans orii habitats; we concentrated on locating cavities $<4 \mathrm{~m}$ above the ground.

\begin{tabular}{|l|c|c|c|}
\hline \multirow{2}{*}{ Variable } & \multicolumn{2}{|c|}{ Habitat } & \\
\cline { 2 - 4 } & $\begin{array}{c}\text { A. sachalinensis- } \\
\text { dominated }\end{array}$ & P. jezoensis- dominated & $P^{*}$ \\
\hline Cavity trees & & & \\
Height (m) & $19.01(7.92), \mathrm{n}=33$ & $18.29(8.23), \mathrm{n}=39$ & 0.71 \\
DBH $(\mathrm{cm})$ & $34.54(17.87), \mathrm{n}=41$ & $43.75(26.30), \mathrm{n}=47$ & 0.12 \\
DCH $(\mathrm{cm})$ & $45.81(38.65), \mathrm{n}=44$ & $45.54(27.84), \mathrm{n}=52$ & 0.41 \\
& & & \\
\hline Cavities & $1.29(0.75), \mathrm{n}=45$ & $1.50(0.81), \mathrm{n}=57$ & 0.14 \\
Height above ground (m) & $15.16(12.52), \mathrm{n}=45$ & $12.29(10.96), \mathrm{n}=57$ & 0.12 \\
Longest diameter $(\mathrm{cm})$ & $4.90(3.06), \mathrm{n}=45$ & $5.16(3.16), \mathrm{n}=57$ & 0.72 \\
Shortest diameter $(\mathrm{cm})$ & $2.55(2.52), \mathrm{n}=45$ & $1.03(2.04), \mathrm{n}=57$ & $<0.01$ \\
Thickness of entrance margin $(\mathrm{cm})$ & $14.24(33.34), \mathrm{n}=45$ & $2.30(4.72), \mathrm{n}=57$ & $<0.01$ \\
Length from entrance to inner wall $(\mathrm{cm})$ & $12.73(8.62), \mathrm{n}=45$ & $11.22(7.46), \mathrm{n}=57$ & 0.40 \\
\hline
\end{tabular}

*Mann-Whitney's $U$-test 
cavity trees did not significantly differ in height, $\mathrm{DBH}$, and DCH $(P>0.05$, Table 2$)$. The cavities also did not differ in height above ground, longest diameter, shortest diameter, and length from entrance to inner wall $(P$ $>0.05)$. Thickness of entrance margin and depth were significantly greater in the $A$. sachalinensis-dominated habitat than in the $P$. jezoensis-dominated habitat $(P<$ 0.01 ) (Table 2). Only 4 cavities in live trees were used by $P$. volans orii in the $A$. sachalinensis-dominated habitat. No cavities were used in the $P$. jezoensisdominated habitat.

\section{Discussion}

Number of cavities found in the $A$. sachalinensisdominated habitat was similar to that in the $P$. jezoensis-dominated habitat, showing cavity resources were similar in these two different habitats. In the $A$. sachalinensis-dominated habitat, $50 \%$ of cavities were found on $A$. sachalinensis. Even in the P. jezoensis-dominated habitat, $25 \%$ of cavities were on $A$. sachalinensis, although the most cavity abundant tree was $P$. jezoensis (31.92\% of total number). Pteromys volans orii may find $A$. sachalinensis more useful in nesting. In fact, $P$. volans orii most frequently nests in $A$. sachalinensis in northern Hokkaido (52.80\%; Nakano et al., 1991) and eastern Hokkaido (33.33\%; Masuda, 2003). Pteromys volans orii may have more opportunity to nest $A$. sachalinensis because it had the most cavities.

Between two different habitats, cavity trees did not differ in most measurements (Table 2), showing that the similar sized trees have cavities. Thickness of entrance margin and the cavity depth were significantly greater in the $A$. sachalinensis-dominated habitat than in the $P$. jezoensis-dominated habitat (Table 2). Cavities in the A. sachalinensis-dominated habitat may have tougher entrance and wider interior space than those in the $P$. jezoensis-dominated habitat. Nakano et al. (1991) reported that the nest space of $P$. volans orii was $18 \times 18$ X $56 \mathrm{~cm}$ in northern Hokkaido. Masuda (2003) showed that nest depth was $27.5 \mathrm{~cm}$. Therefore, wider interior space could be important for nesting of $P$. volans orii. This may mean that $A$. sachalinensis-dominated habitat provides more useful cavity nests for $P$. volans orii. Unfortunately, it is difficult to identify why thickness of entrance margin and depth differed between two habitats. Further studies should examine the relationship between these two cavity measurements and how the cavities are made.

We found $P$. volans orii using only four cavities in the $A$. sachalinensis-dominated habitat and none in the $P$. jezoensis-dominated habitat. Our data, however, are insufficient to state that $P$. volans orii prefers the $A$. sachalinensis-dominated habitat to the $P$. jezoensisdominated habitat. Of the four cavities used by $P$. volans orii, all were on live trees. Masuda (2003) and Asari et al. (2009) reported that $P$. volans orii nested more in live trees than snags. Our finding also may support these previous reports, but it was not conclu- sive due to few data. The $A$. sachalinensis-dominated habitat may provide more useful nest resources for $P$. volans orii than the $P$. jezoensis-dominated habitat. This endemic flying squirrel subspecies might have successfully adapted itself to the unique $A$. sachalinensis-dominated forests located on the periphery of the $P$. volans distribution. To further understand the habitat preference of $P$. volans orii, however, food resources must be considered. Pteromys volans orii may preferentially use food resources in A. sachalinensis habitat or in $P$. jezoensisi habitat. Information of both nest and food resource preferences may clarify the habitat preference of $P$. volans orii.

\section{ACKNOWLEDGEMENTS}

We appreciate the support and field assistance provided by Y. Igarashi, A. Kato, K. Ishii, M. Noda, M. Matsuhashi, R. Haraguchi, S. Sato, Y. Kondo, K. Akashi, Y. Nojima, K. Washinosu, K. Ono, and A. Ieiri. We thank H. Yanagawa and Y. Konno for helpful comments. We are grateful to C. L. Bridgman for her critical reading of the manuscript. This study was partially supported by the Grant-in-Aid for Scientific Research No. 21380086 from the Ministry of Education, Science, Sports, and Culture, Japan.

\section{References}

Airapetyants A.E. \& Fokin I.M. 2003. Biology of European flying squirrel Pteromys volans L. (Rodentia: Pteromyidae) in the north-west of Russia // Russian Journal of Theriology. Vol.2. No.2. P.105-113.

Asari Y., Nakama S. \& Yanagawa H. 2009. Investigation of tree cavities used by Siberian flying squirrels and their selectivity factor // Journal of Japan Wildlife Research Society. Vol.34. P.16-20 [in Japanese with English abstract].

Hanski I.K. 1998. Home range and habitat use in the declining flying squirrel Pteromys volans in managed forests // Wildlife Biology. Vol.4. P.33-46.

Hanski I.K., Mönkkönen M., Reunanen P. \& Stevens P. 2000. Ecology of the Siberian flying squirrel (Pteromys volans) in Finland // Goldingay R.L. \& Scheibe J.S. (eds.). Biology of Gliding Mammals. Fürth: Filander Verlag. P.67-86.

Kuroda N. 1921. On three new mammals from Japan // Journal of Mammalogy. Vol.2. P.208-211.

Masuda Y. 2003. Notes on nesting trees of the flying squirrel (Pteromys volans orii) // Bulletin of the Shiretoko Museum. Vol.24. P.67-70 [in Japanese].

Nakano S., Hino T., Natsume S. Hayashida M., Inaba Y. \& Okuda A. 1991. Notes on nesting trees of Japanese flying squirrel, Pteromys volans orii, in Hokkaido during winter // Bulletin of the College Experiment Forests, Hokkaido University. Vol.48. P.183-190 [in Japanese].

Novikov G.A., Airapetyants A.E., Pukinskii Y.B., Strelkov P.P. \& Timofeeva E.K. 1970. [Mammals of the Leningrad Province]. Leningrad: Izdatel's stvo Leningradskogo Universiteta. [in Russian] 
Ognev S.I. 1966. Mammals of the U.S.S.R. and Adjacent Countries. Vol.4. Jerusalem: Israel Program for Scientific Translation. 429 pp.

Oshida T., Abramov A., Yanagawa H. \& Masuda R. 2005. Phylogeography of the Russian flying squirrel (Pteromys volans): implication of refugia theory in arboreal small mammal of Eurasia // Molecular Ecology. Vol.14. P.1191-1196.

Reunanen P., Mönkkönen M. \& Nikula A. 2002. Habitat requirements of the Siberian flying squirrel in northern Finland: comparing field survey and remote sensing data // Annales Zoologici Fennici. Vol.39. P.7-20.

Satake Y. 1989. Pinaceae // Satake Y., Hara H., Watari S. \& Tominari T. (eds.). Wild Flowers of Japan: Woody Plants.
Tokyo: Heibonsha Ltd. P.5-14.

Wilson D.E. \& Reeder D.M. (eds.). 2005. Mammal Species of the World: A Taxonomic and Geographic Reference. Third Edition. Baltimore: The Johns Hopkins University Press. 2142 pp.

Yamamoto H., Nitami T. \& Kisanuki H. 1995. Stand structure of mixed-species stands (I) Relation of species composition and topographic factors // Journal of the Japanese Forestry Society. Vol.77. P.47-54 [in Japanese with English abstract].

Yanagawa H. 1999. Ecological notes on the Russian flying squirrel (Pteromys volans orii) with a video camera // Honyurui Kagaku [Mammalian Science]. Vol.39. P.181183 [in Japanese]. 